\title{
"Municipal Inducements"_-The New Mexico Commercial and Industrial Project Revenue Bond Act
}

\author{
Arthur O. Armstrong, Jr.*
}

WW of ordinary income into the more precious stuff of capital gains, the State of New Mexico has unobtrusively left upon his hearth a catalyst which holds promise of producing the pure gold of tax-exempt income. This tantalizing agent is known as the "New Mexico Commercial and Industrial Revenue Bond Act." To him who would experiment with this new ingredient, there remains but a single question: Will it in fact produce the promised glittering reward, or will it serve only to destroy that with which it is mixed?

As always with questions raised by new concepts, the answer must be sought in historical antecedents, and common sense. Definitive analysis is impossible, for the problems are by their nature to some extent unique. There are, however, situations sufficiently analogous to permit informed speculation. It is the purpose of this exposition to consider some of the problems raised by the New Mexico statute in the light of these analogous situations, so as to stimulate thinking as to the possible uses of the statute. As will be demonstrated, resolution of particular problems is going to require intensive research based on unique facts. It is, therefore, hoped that none will be misled by the occasional oversimplifications and overgeneralizations, which seemed necessary in order to retain the thread of the argument.

I

MUNICIPAL INDUCEMENT PLANS ${ }^{2}$

The history of the industrial development of the United States is liberally sprinkled with stories of the attempts by various governmental agencies, acting in what was deemed to be the best interests of the citizenry, to attract new businesses to areas suffering from underdevelopment and an

* Member, Los Angeles Bar. This Article is based on remarks of the writer to the members of the New Mexico Municipal League, on September 24, 1959.

1 N.M. Stat. Ass. $\$ \$ 14-41-31$ to -43 (Supp. 1959).

2 See, for an excellent discussion of the material here discussed, Note, Legal Limitations on Public Inducements to Industrial Location, 59 CoLUM. L. REv. 618 (1959). For those interested in the area, the work is an invaluable beginning point. 
imbalanced economy. ${ }^{3}$ It is true that the only sound basis for the creation of any new enterprise in any location is the economic desirability of such creative business activity. It is further true that the only real inducement for industrialization of an area will lie in such factors of the economic environment as accessibility to raw materials, accessibility to markets, availability of a labor pool, climate, relative severity of local tax burdens, and restrictiveness of so-called "social legislation." These, however, are not factors generally classed as "municipal inducements." Rather, that phrase has been reserved for plans whereby a local governmental agency attempts to add to its natural attractions some artificial stimulus to the development of the local economy. It is with "municipal inducements" of this latter type that we are here concerned.

The basic idea behind all of the various schemes of "municipal inducement" is to make location of a business in a particular community financially attractive by promise of increasing profits directly, or indirectly through reducing costs of operation. This can be accomplished in any one of several ways.

\section{A. The Early Plans}

\section{Tax exemptions}

The commonest form of "inducement" is the granting of tax exemptions to new businesses. Under these plans a new business is exempted from specified state and/or local taxes for a specified period of time. The kind of business to which this advantage is offered, the taxes to which it applies, and the duration of the exemption vary from State to State, but the general idea is the same in all of the some 14 to 20 States which use this type of inducement. ${ }^{5}$

\section{Gifts}

Another "inducement" is the outright gift of money or property to new businesses. Although some municipalities have in the past attempted to

3 One set of figures sets forth the following somewhat startling consequences to a community from the addition of a new business employing 150 workers: plant investment of $\$ 100,000$; new payroll of $\$ 200,000$ per year; support for 1,000 persons; 2 stores; a 10-room school house; sales and services for 200 cars; railroad revenues of $\$ 60,000$ per year; support for 12 professional men; a $\$ 300,000$ market for farm products. Clark, MI unicipal Industrial Bonds-Benefits and Dangers, American City, March 1952, p. 114. But see Note, 66 HARv. L. REv. 898, 908 n.99 (1953), stating that Clark's source has no knowledge of such a survey.

* See Garwood, Are Muricipal Subsidies for Industrial Location Sound?, American City, May 1953, p. 110; Lowry, City Subsidies to Industry Wante, 34 NAT'L MuNic. Rev. 112 (1945) (written before revenue bond statutes became so important); Note, supra note 2 ; Note, $M u$ ricipal Inducements To Private Industry, 40 Minv. L. Rev. 681, 692 (1956); Note, 66 Harv. L. REv. 898, 907 (1953).

5 See Note, supra note 2 ; Note, 40 MrN. L. Rev. 681, 684 (1956). The question whether such an exemption is afforded under the New Mexico statute here considered is discussed in text at, and textual material accompanying, notes 113-18 infra. 
make such gifts without specific statutory authorization, ${ }^{6}$ it is generally regarded-absent such specific authorization-as an improper expenditure of public funds. ${ }^{7}$ Even an authorizing statute is not effective, where there are, as in most States, constitutional provisions prohibiting "giving aid" or "lending credit" to private parties. ${ }^{8}$ At present, Mississippi appears to be the only State that has established a definite program authorizing such donations, ${ }^{9}$ and even in that State it is now the policy to avoid outright grants and to work within the frame of bona fide transfers for consideration. ${ }^{10}$

\section{Assistance in Financing Construction of Facilities}

A third form of "inducement" is assistance to a business in the financing of construction necessary to establish a new employment-creating facility within the municipality. These schemes date back at least as far as the early 1830's, and have enjoyed renaissances in the 1880's, 1920's and again in the present. ${ }^{11}$ All of them contemplate the municipality's receiving an equivalent consideration for the money or other property turned over to the business. Early plans of this type involved subscription to the capital stock of canal and railroad companies by the municipalities which hoped to be served by these transportation agencies. The funds for the contributions were generally obtained through the issuance of general obligation bonds or the levying of taxes. All too frequently the alleged transportation company was little more than a promotional bubble, and many municipalities became seriously involved financially as a result of the failure of these enterprises. Later, there was a movement towards municipal construction of industrial facilities to be rented to relocating manufacturers. Because of the constitutional prohibitions against "giving of aid" and "lending of credit," it was frequently necessary to disguise these transactions as something other than what they in fact were by devices so transparent as to be not even devious, such as maintaining the fire chief's office on the ground floor of a building, labeling it a fire house, and renting the "unused" portions to an industrial concern. Again, in these instances, the buildings were usually constructed out of general funds of the municipality, or moneys obtained through the issuance of general obligation bonds.

6 Lowry, supra note 4; Note, supra note 2, at 623.

7 See 15 MCQumins, Munictrai. Corporatrons \$39.26 (3d ed. 1950); 16 id. $\$ 44.40$.

${ }^{8}$ See generally $15 i d$. 839.26 . See text at, and textual material accompanying, notes 111 infra, as to New Mexico's constitutional restrictions.

9 Miss. CODE ANN. \$\$8936 to 8936-24 (1956). See text at notes 12-16 infra.

10 See text at note 15 infra; Jones, Federal Income Tax Deductions of BAWI Leasehold Payments, 30 Miss. L.J. 10 (1958). Californians, and owners of professional sports organizations, should draw their own conclusions from City of Los Angeles v. Superior Court, 51 C.2d 423, 333 P.2d 745 (1959).

11 Garwood, supra note 4; Note, supra note 2, at 619. 


\section{B. The "Industrial Revenue Bond" Plans}

From the standpoint of the business receiving the inducement, it is probably immaterial in what precise form the benefits are extended. The determining factor is the dollar value of the benefits. On the other hand, from the standpoint of the community extending the inducement the precise form of the benefit is of importance. Each of the plans mentioned above is subject to the objection that it involves the expenditure, or the risk of expenditure, of public moneys, either directly, or indirectly through the municipality's furnishing services without proper compensation from the benefited industry. The ideal plan from the municipality's point of view would be one that did not and could not cost local taxpayers any money, but that still provided some tangible benefits for "inducing" the businessman. It was to attain these ends that the industrial revenue bond plans were developed.

\section{Mississippi's BAWI ${ }^{12}$ Plan}

The present industrial revenue bond plans can undoubtedly claim direct descent from Mississippi's famous BAWI Plan, adopted in $1936^{13}$ as a move to combat a truly serious depression situation in that State. Essentially, the statute embodying the plan created a state commission to supervise the issuance by municipalities of general-obligation bonds to obtain funds for the construction of industrial facilities. These facilities would then be operated either by a private business which had been induced to come to the area, or, if necessary, by the city itself. While the bonds were general-obligation bonds, it was anticipated-in most instances then, ${ }^{14}$ and in all instances now ${ }^{15}$-that the rentals from the facility, or the revenues from its operation, would be sufficient to fund the bonds. There have been generally sanguine reports as to the success of the BAWI Plan. ${ }^{16}$

\section{Revenue Bond Statutes}

The BAWI Plan was tremendously flexible. Under it, a municipality could virtually give away a manufacturing facility as an inducement to re-

12 An agglomeration of the initial letters of "Balance Agriculture With Industry."

13 Miss. Laws 1936, 1st Ex. Sess., ch. 1. The original statute expired in 1940 and was re-enacted in 1944. It may be found in Miss. Cone ANN. $\$ \$ 8936$ to 8936-24 (1956).

14 HopkINs, Mississippi's BAWI PIAN 29 (1944). But see id. at 47, describing a transaction in which Armstrong Tire was permitted to occupy a plant constructed by the City of Natchez at a cost of $\$ 290,000$ for rentals of $\$ 600$ per year.

15 See Jones, supra note 10.

16 See HopkINs, MIIssissIrpi's BAWI PLAN (1944). From 1936 to 1940, 12 companies leased plants from 10 cities, $i d$. at 39; in 1943 employment in BAWI plants reached 13,000, being $14 \%$ of the employment and $24 \%$ of the payroll in the State's manufacturing industry, id. at 54-55. But by 1951 employment in these plants was down to 5,000. Miss. Agricultural \& Industrial Bd., Progress Report on BAWI (1952).

From 1944 to 1953,57 new plants employing 11,000 were added to the original 12, 16 more were under construction, and 10 contracts were in negotiation. Ibid. 
location; or, it could restrict the benefit conferred upon the manufacturer to the right to have the city finance construction of the facility, the manufacturer being obligated to repay to the municipality the cost of the construction. Of course, even this would yield a dollar advantage: The municipality would have obtained the funds necessary for the construction through issuance of tax-exempt bonds, so that the total financing cost would be lower than that which the business would incur were it to arrange for financing independently. ${ }^{17}$ In addition, the municipality could lease the property to the business, instead of making an outright sale, thus permitting the business to enjoy the benefits of "sale and lease-back" financing of the new facility. ${ }^{18}$ The "revenue bond" plans are a variation of the BAWI Plan. They were designed to offer these advantages to businesses, without the disadvantage to the municipality of financing through generalobligation bonds. ${ }^{19}$

The first of the revenue bond schemes was adopted by Alabama in $1951^{20}$ after two years of experience with an industrial development commission form. ${ }^{21}$ Since that time at least two States have adopted almost identical statutes, ${ }^{22}$ and six others have adopted legislation or constitutional amendments designed to accomplish the same end, although couched in

17 See text at notes $32-42$ infra.

18 See text at notes $45-60$ infra.

10 In theory, of course, the "revenue bond" is distinguished from the "general obligation" in that the former cannot be a charge on the general credit of the issuing municipality, the holders being limited by their contract to a right against only the revenues derived from operation of the particular facility financed with the proceeds of issuance of the bonds.

But it is important to note that the holders may have other means of recourse against the issuing agency, based on misrepresentation, negligence, breach of an implied covenant or warranty, breach of trust or some other theory circumventing the attempted limitation of the obligation of the city. The classic discussion is in Fordham, Revenue Bond Sanctions, 42 Convar. L. Rev. 395 (1942). Cf. Hauge v. City of Des Moines, 207 Iowa 1209, 224 N.W. 520 (1929).

For instance, were a municipality to enter into a transaction which was, on its face, impossible of succeeding, might not a bondholder be able at least to raise the argument that the city had been negligent in permitting the issue of bonds under its name, or that there was an implied misrepresentation in the issuance of bonds for such a project, or that there was a breach of an implied covenant of good faith? Obviously, such arguments would only be possible where there were blatant abuses of the power of cities to issue revenue bonds. However, it is perhaps worth noting that the situation would be reviewed at a time when any possible defects in the original plan had borne their bitter fruit-the bonds would have gone bad. Even granting that the test would be the situation at tbe time of issuance, elements of hindsight would be difficult to dispense with in analysis of the obligation of the city in connection with the issuance.

$2 n$ ALA. Code tit. 37, \$\$ 511(20)-(32) (Supp. 1955). Of course, revenue bonds had been used extensively by municipalities before this time in other types of financing. See Foley, Revenue Financing of Public Enterprise, 35 Mrcr. L. REv. 1 (1936); cf. N.Y. Laws 1851, ch. 485, held illegal in Sewell v. People ex rel. Phelps, 7 N.Y. 9 (1852).

21 Ala. Code tit. 37, \$\$ 815-30 (Supp. 1955).

22 Neb. Rev. Stat. \$\$ 18-1601 to -1613 (1954) (declared unconstitutional in State ex rel. Beck v. City of York, 164 Neb. 223, 82 N.W.2d 269 (1957)) ; N.D. Rev. Code $\$ \$ 40-5701$ to -5718 (Supp. 1957). 
slightly different language, and with various mechanical and procedural deviations. ${ }^{23}$

The Alabama statute revolved about the term "project," which is therein defined as:

Any land and any building or other improvement thereon, and all real and personal properties deemed necessary in connection therewith, whether or not now in existence $\ldots . .^{24}$

Municipalities are authorized to acquire "projects" located within the municipality, or within a specified number of miles outside its limits; to issue revenue bonds for the purpose of acquiring "projects" and to sell or lease the "projects" for a price or at rentals sufficient to fund the bonds and the interest thereon..$^{25}$ In order to prevent speculative building, the statute requires that before any bonds be issued the municipality have entered into an agreement with a prospective purchaser or lessee, conditioned only upon completion of the "project." 28

\section{The New Mexico Plan}

In the year 1955, the Legislature of the State of New Mexico, with some prodding ${ }^{27}$ brought forth a statute ${ }^{28}$ deceptively comparable to the Alabama version in appearance, but vitally different in effect. Through a slight modification of the definition of the critical term "project," it was intended that a statute be created under which a municipality could acquire not just a manufacturing facility, but rather, an entire going business.

Mechanically, this transformation was accomplished through expanding the definitional clause to read:

"Project" means any land, and building or other improvements thereon, the acquisition by or for a New Mexico corporation of the assets or stock of an existing business or corporation located outside the state of New Mexico to be relocated within or near the municipality in the state of New $M e x i c o$, and all real and personal properties deemed necessary in connection therewith ....29

The balance of the statute is an almost verbatim copy of the Alabama

23 ILx. Anv. Stat. ch. 24, \$§ 1211-24 (Smith-Hurd Supp. 1959); Ky. Rev. Stat. \$\$ 103.200.280 (1959); LA. CoNst. art. XIV, § 14(b2); Md. Acts 1953, ch. 662, \$ 103 (special charter provision); Tenn. Code ANN. § 6-2901 to-2916 (Supp. 1958); VT. Stat. ANN. tit. 24, \$\$ 2701-14 (1959). See Note, Legal Limitations On Public Inducements to Industrial Location, 59 ColvM. L. REv. 618, 629-38 (1959); Note, 66 HARv. L. REv. 898 (1953).

24 ALA. CODE tit. 37, § 511(20) (Supp. 1955).

25 AIA. CODE tit. 37, § 511(22) (Supp. 1955).

26 ALA. CODE tit. 37, § 511 (25) (Supp. 1955).

27 See Business Week, Aug. 9, 1958, p. 33.

28 N.M. StaT. ANN. $\$ \$ 14-41-31$ to -43 (Supp. 1959).

29 N.M. Stat. ANN. § 14-41-31 (Supp. 1959). (Emphasis added.) 
statute, ${ }^{30}$ authorizing, inter alia, municipalities to acquire "projects" located within the limits of the municipality issuing the bonds, or within 15 miles of its limits; to issue revenue bonds to defray the cost of acquisition; and to sell, lease, or dispose of the "project" under a contract yielding sufficient money to pay off the bonds issued for its acquisition. ${ }^{31}$

Unfortunately, as is so often the case with the drafting of statutes, the intent of the legislature lost something in the verbalization. That partial frustration of intent has led to some difficulties, which can perhaps best be discerned in the light of the methods by which it was intended the statute might be used.

\section{II}

\section{BENEFITS OF INDUSTRIAL REVENUE BOND PLANS}

Obviously, in any situation in which a business is asked to relocate or to expand in a new community, one of the most immediate problems will be that of financing the creation of the new facility. If the municipality seeking to attract the business can offer financing, this potential block is eliminated. To some extent, the ordinary revenue bond statutes perform just this function. But these plans can also serve another function which makes them intriguing to the tax-planner. This other function is found in the potential which they offer for enjoying the substantial tax advantages afforded to instrumentalities of local government under the Internal Revenue Code. And it is the availability of such advantages that will determine whether these plans can become true "inducements" in the crasser and more profitable sense now connoted by that term.

\section{A. Tax-Exempt Treatment of Interest on Municipal Bonds}

Probably the best known of the tax advantages of municipalities is the exemption of inunicipal bond interest from federal income taxes. ${ }^{32}$ The effect of this exemption would theoretically be to reduce the interest costs of borrowing by the average of the tax rates of all of the holders of bonds..$^{33}$ For instance, assuming that the financing of an industrial facility costing

30 The few changes made in the statute, other than the expansion of the definitional clause did no more than modernize some rather archaic terminology, probably peculiar to Alabama practice. Substantively, the only other apparent change was the addition to the description of costs properly includible in the financing of the cost of extending utilities to the site of the "project."

31 N.M. Stat. ANw. § 14-41-33 (Supp. 1959).

82 INT. REv. CODE OF 1954, \& 103 (a) (1). See text at notes 119-22 infra.

83 In actuality, the apparent preciseness of mathematical averaging would be misleading, since typically, the higher the tax rate, the more money available for investment, and the greater the desire for tax-exempt investments. Thus, it would probably be found that in any particular municipal bond issue the distribution of tax rates among holders would show larger holdings among those with higher tax rates. 
$\$ 1,000,000$ is to be handled through the issuance of ordinary 6-percent corporate bonds payable serially over a 20 -year life, the total interest cost will be $\$ 630,000 .^{3 *}$ This means, taking into account the deductibility of the interest payment, ${ }^{35}$ a reduction in after-tax profits of $\$ 315,000 .^{30}$ If a corporation could issue tax-exempt bonds, then, assuming that the current market ratio between exempt and taxable bonds of approximately 70 percent were to prevail, ${ }^{37}$ the interest rate on the bonds could be reduced to 4.2 per cent, ${ }^{38}$ thus reducing the interest over the life of the obligation to $\$ 441,000,{ }^{39}$ with the effect of reducing after-tax profits by $\$ 220,500.4^{40}$

Comparing these two interest-cost figures, it appears that a business could save $\$ 94,500^{11}$ over a 20 -year period through the use of tax-exempt bonds, or .9 percent per year on the outstanding principal amount of indebtedness. ${ }^{12}$

\section{B. Transactions Involving Exempt Organizations}

The other tax advantage of a municipality lies in its immunity from income tax upon receipts of every description..$^{43}$ This immunity makes possible the use of "leaseback" financing devices and the "sale to charity" schemes which were popular manipulations of the exempt status of certain charitable organizations prior to the 1950 amendments to the Internal

34 Assuming a retirement program calling for redemption of equal amounts of bonds each year, or $\$ 50,000$ per year for the full 20 years. At $6 \%$, the interest in the first year would be $(\$ 1,000,000 \times .06)$ or $\$ 60,000$, and in the last year $(\$ 50,000 \times .06)$ or $\$ 3,000$. For any given year the interest would be $[\$ 50,000 \times(21-N) \times .06]$. Therefore, the sum of all of the interest would be $[.06(\$ 50,000) \times(1+2+3 \ldots+20)]$ or $(\$ 3,000) \times \frac{21 \times 20}{2}=(\$ 3,000) \times 210$ $=\$ 630,000$.

35 INT. REv. CODE OF 1954, 163 (a).

36 Throughout, for convenience, corporate income taxes have been regarded as $50 \%$, although the actual rate, on income over $\$ 25,000$, is $52 \%$. INT. REv. CODE of 1954, $\$ 11$.

37 Based on figures from Wall Street Journal, Sept. 23, 1959.

$38(.06) \times(.70)=.042$.

${ }^{39}$ As in note 34 supra: $(.042) \times \$ 50,000 \times \frac{21 \times 20}{2}=(2,100) \times 210=\$ 441,000$.

10 One-half of $\$ 441,000$.

$41 \$ 315,000$ less $\$ 220,500$.

12 Which is, of course, $50 \%$ of the $1.8 \%$ reduction in interest rate.

13 INT. REv. CODE OF 1954, §115(a) provides a statutory exemption. In this area, if anywhere, the doctrine of intergovernmental immunity from taxation would be most viable. From a standpoint of constitutional doctrine, however, it would seem that income derived from the operation or leasing of industrial projects might well not be deemed within whatever remains of the prohibition upon taxation of income from "governmental" operations. New York v. United States, 326 U.S. 572 (1945).

It should also be noted that $\S 115$ (a) uses the term "income derived from any . . . essential governmental function ..." to delimit the scope of the exemption. This is apparently coextensive with the constitutional immunity. See Flint v. Stone Tracy Co., 220 U.S. 107 (1911). However, the Internal Revenue Service has taken the position, and adhered to it for many years, that no reccipts accruing to a inunicipality are subject to taxation. Tbis position was formulated in G.C.M. 14407, XIV'-1 CUM. BLII. 103 (1935), modifying and revoking I.T. 2797, 
Revenue Code. ${ }^{4 t}$ These are considered below.

\section{1. "Lease" Financing"s}

The advantages of "lease" financing can be illustrated through an expansion of the example above, adding the information that of the total facility cost of $\$ 1,000,000, \$ 200,000$ is allocable to land and $\$ 800,000$ to the building, which has a useful life of 40 years.

The servicing of the bonds will require an outlay of $\$ 50,000$ for principal in each year of the 20-year life of the bonds, and interest payments of $\$ 60,000$ in the first year, ranging downward in $\$ 3,000$ intervals to $\$ 3,000$ in the last year. ${ }^{16}$ In each year the tax deductions available in connection with the facility will be the total of the interest paid, plus a depreciation deduction for the building, which, on a straight-line basis, ${ }^{17}$ would be

XIII-2 CuM. Bulx. 74 (1934); I.T. 2820, XIII-2 CuM. Burc. 77 (1934); and G.C.M. 13745, XIII-2 CuM. BuIL. 76 (1934). The earlier rulings took contradictory positions on the taxability of revenues derived from operation of state liquor stores. I.T. 2797, supra, held such receipts taxable. I.T. 2820 and G.C.M. 13745, supra, took the position that since a large part of the profits accruing to the State from the stores was used in carrying out essential governmental functions that a tax on the profits would burden the State in the exercise of such functions and, therefore, the profits would be immune. This argument, which coines close to the constitutional one, but at the same time would make all receipts of a governmental agency immune, was rejected and the present position adopted in G.C.M. 14407, in which the Service took the position that the Internal Revenue Act did not contemplate taxation of the income of municipalities. This was based on a rather strained interpretation of the Code, and on the doctrine of "contemporaneous administrative construction" and "legislative re-enactment," the Bureau stating in effect that they had never before tried to tax local governmental agencies, and did not wish to start now, without some specific congressional mandate. See also Omaha Pub. Power Dist. v. O'Malley, 232 F.2d 805 (8th Cir. 1956); Keokuk \& Hamilton Bridge, Inc. v. Commissioner, 180 F.2d 58 (8th Cir. 1950) ; Bear Gulch Water Co. v. Commissioner, 116 F.2d 975 (9th Cir. 1941); Citizens' Water Co. v. Commissioner, 87 F.2d 874 (8th Cir. 1937); Counmissioner v. Turney, 82 F.2d 661 (5th Cir. 1936) ; Rev. Rul. 59-41, 1959 INT. Rev. Buur. No. 5, at 8; Rev. Rul. 57-151, 1957-1 Cum Bull. 64; Rev. Rul. 54-296, 1954-2 CuM. Buxz. 59.

44 Revenue Act of 1950, $\$ 331,64$ Stat. 957 (enacting $\$ \$ 3813-14$ of Int. Rev. Code of 1939) (now Ist. REv. CODE of 1954, $\$ \$ 503,504$ ). For a discussion of the effect of these amendunents, see text at notes 65-69 infre.

45 In the discussion below, "lease" financing is considered strictly from a tax standpoint. No attempt is made to delve into such problems as the gain or loss on the "sale," or the peripheral advantages claimed for this type of financing, such as "cleaning up the balance sheet." Tax literature abounds in lengthy discussions of all the problems in the area. A classic exposition is Cary, Sale and Leaseback Financing, 62 Harv. L. REv. 1 (1948). See also Cohen \& Meisel, A Later Look at the Sale and Leaseback, 5 Sr. Lovis U.L.J. 169 (1958); Bernard \& Peristadt, Sale and Leaseback Transactions, 1955 U. InI. L.F. 635 ; Lassers, Does a Leaseback Save You Money?, 32 Taxes 279 (1954); Friedman, Eqaipment Transactions, N.Y.U. 14Tr INST. ON FED. TAX 1427 (1956); cf. note 52 infra.

16 See note 34 supra.

47 Under INT. REY. CODE of 1954, $\$ 167$ (b), one of the accelerated methods could be used, raising the deduction to $\$ 40,000$ in the first year, and progressively smaller amounts in subsequent years. The mathematical analysis would be comparable to, but more complex than, the following. The existence of these new methods may well relieve some of the pressure for leasing transactions. 
$\$ 20,000$ per year..$^{48}$ This would leave a nondeductible expenditure in repayment of the loan of $\$ 30,000$ per year..$^{49}$ Of this amount $\$ 20,000$ per year will be recovered through depreciation deductions in the years after bond retirement, ${ }^{50}$ and $\$ 10,000$ per year-representing the value of the landwill not be recovered as a tax deduction until the property is sold, at which time it will become an offset in the form of basis against the amounts received on the sale and will tend to reduce a possible capital-gains tax on the sale..$^{51}$

Lease financing holds out the promise of capturing these tax dollars. Mechanically, the procedure is simple. Rather than casting the transaction as a loan, with the payments being denominated "repayment," it is treated as a sale to the "lender," followed by a lease to the borrower" with the payments being denominated "rent." If the "rent" payments are equal to the amounts which would otherwise have been paid under a conventional financing, there will be a tax savings through the 20-year period of $\$ 300$,000 , or an average of $\$ 15,000$ per year. ${ }^{53}$

To complete the picture, however, it must be noted that there is one striking difference between lease financing and conventional financing. At the end of the repayment term in conventional financing, the mortgagor receives clear title to the property without any additional payment. On termination of a lease, the lessee has no right to continued use of the property. In the illustration above, assuming that land values remain constant, and that economic depreciation is on a straight-line basis, lease financing involves the loss of property with a value of $\$ 600,000 .{ }^{54}$ There are two solutions to this problem. One is to compute the cost of funding this amount by nondeductible contributions to a sinking fund over the term of the lease. If the tax benefits exceed this funding cost, then the leaseback is desirable. In the example above, the actuarial cost of such an accumulation would be

$48 \$ 800,000 / 40=\$ 20,000$.

$19 \$ 50,000$ less $\$ 20,000$.

50 Assuming that the facility were retained for its full useful life, there would be depreciation in each year from the 21st to the 40th, of the same amount as during each of the first 30 years.

61 Obviously, the least desirable of all deductions, being offset against income subject to the favorable capital-gains tax rates.

52 The same general principles apply in the cases of alleged "leasings" which are in fact installment sale contracts. See Rev. Rul. 55-540, 1955-2 Cuxs. Bux.r. 39, setting forth the Treasury position in detail; applied in Rev. Rul. 57-371, 1957-2 Cusc. Buxd. 214. See also Friedman, supra note 45.

63 The value of the deductions not available under conventional financing would anount to $\$ 600,000$, being $20 \times \$ 30,000$. One-balf of this amount would be $\$ 300,000$.

of Of course, there are a host of assumptions implicit in this figure other than those here expressed. The primary one is whether the alleged value of the property is an actual measure of its worth to the borrower. 
$\$ 22,329$ per year, or a total of $\$ 446,580,{ }^{55}$ so that there would be a yearly net loss from leaseback financing of $\$ 7,329$.

The other solution is the inclusion in the lease of a "recapture" clause, entitling the "lessee" to renewals of the lease over the balance of the useful life of the property at nominal rentals, or to purchase the property for a nominal price. 50

From the standpoint of the ordinary lender, lease financing involves the reverse of the considerations set forth above. Since the entire amount of "rents" received will be subject to tax, the net amount retained of the total paid over the term of the lease will be reduced by the taxes on the excess of rents over depreciation ${ }^{57}$ and the "imputed interest" 58 portion of the rents. In exchange for this reduction, the lender will receive the right to the property at the end of the term, unless there is a "recapture clause" in the lease. Lenders having never been noted for dedication to eleemosynary principles, it must be assumed that a charge will be imposed, in the form of increased rents, which will more than offset any hoped-for advantage to the borrower from this form of financing.

But if the lender is in a lower tax bracket than the borrower, then the advantages of lease financing to the borrower will outweigh the disadvantages to the lender. And if the lender is exempt or immune from taxation, then, of course, the format of the transaction is a matter of indifference to the lender. Where, therefore, lease financing seems indicated for the borrower from a tax standpoint, it is desirable to enter into the transaction with an organization enjoying tax rates lower than the borrower, or an exemption from income taxes. Normally, however, the only readily available source of funds would be a commercial lender.

Prior to the 1950 amendments to the Internal Revenue Code, ${ }^{50}$ the solution was the interposition of an exempt organization between borrower and lender. Mechanically, a typical arrangement would call for the borrower to sell his facility to the exempt organization, and then lease it back-the standard "sale and leaseback" transaction. To obtain the funds to consummate the sale, the exempt organization would have entered into a conventional mortgage loan with the lender, the repayment of the loan being restricted to "rents" received from the borrower. ${ }^{80}$ Thus, both borrower

\footnotetext{
55 Sinking fund accumulation at $3 \%$ for 20 years. Factor used is from Smapson, Matmzzatics of Frvasce, table VII (2d ed. 1944).

80 See text at notes 124-36 infra.

57 Since a depreciation deduction will be available to the "lender" in "lease" financing, the rental income will be reduced by this amount for computing taxable income.

58 Since both rental income and interest incoine are taxahle at ordinary income rates, that portion of the "rents" that represents amounts that would otherwise have been paid as interest is subject to no additional tax disadvantage.
}

${ }^{89}$ See note 44 supra.

60 See INT. REv. CODE of $1954, \S 514$ (c), which strikes at just this form of transaction. 
and lender could maximize the tax benefits of the form of the transaction, and, presumably, the exempt organization would not be completely ignored in dividing up that which would otherwise have disappeared into the Treasury.

\section{Sales of Businesses to Charities $^{61}$}

The other method whereby the excmpt status of charitable organizations was manipulated was the "sale to charity" plan. The basis behind such plans was the fact that the best price obtainable for a business that is being sold is one payable out of profits over a period of years. For instance, the purchaser of a business who is willing to pay $\$ 1,000,000$ on a firm basis might well be willing to go as high as $\$ 2,000,000$ payable only out of profits over a 5- or 10-year period.

Of course, where such arrangements are made the payments are nondeductible. Hence the profits being spoken of would be after-tax profits, which would be only 50 percent of profit before taxes. Once more, an organization which enjoys low taxes or no taxes can be useful. If a business is to be sold for 5 years of profits, the seller can reccive twice as much by making the transaction with an exempt organization. And exempt organizations were not above pointing this out to those interested in selling businesses.

Prior to 1950, the standard device for accomplishing sucli a transaction involved the creation of a "feeder" corporation by or on behalf of the taxexempt organization. The feeder corporation would be capitalized for a nominal amount-usually $\$ 1,000 .^{62}$ The business would then be purchased by the feeder, which would give its promissory notes for the entire price to evidence the acquisition. The business would usually continue to be operated by the same management as before the sale (now under contract with the feeder) and all profits (or the bulk of the profits) applied to payment of the notes evidencing the price. After retirement of the indebtedness, the business would be owned outriglit by the feeder, and the parent exempt organization entitled to receive, as dividends, the entire income. Since the income of the feeder was generally believed to be nontaxable, ${ }^{63}$ the price that could be paid for the business was substantially greater than could have been offered by buyers not enjoying tax-exempt status.

By amendment in 1950 to the Internal Revenue Code of $1939^{64}$ the

61 The two leading discussions in this area are in Alexander, The Use of Foundations It Business, N.Y.U. 15TH INsT. Ox FEd. Tax 591 (1957), and MacCracken, Selling a Business to a Charitable Foundation, U. So. Car. 1954 TAx INST. 205. See also Grant, Taxation of Charilable Organizations, 4 U.C.L.A.L. REv. 352 (1957).

62 The minimum capitalization required in many States, including New Mexico. See N.M. Stat. ANn. \$ 51-2-8.4 (1953).

B3 C. F. Mueller Co. v. Commissioner, 190 F.2d 120 (3d Cir. 1951), reversing 14 T.C. 922 (1950) ; Roche's Bcach, Inc. v. CoInmissioner, 96 F.2d 776 (2d Cir. 1938).

os See note 44 supra. 
income of feeder corporations, ${ }^{65}$ and the "unrelated business income" 00 of exempt organizations other than churches ${ }^{67}$ was subjected to tax. These amendments have rendered the "sale to charity" plans substantially unworkable, except where the acquiring organization is a church, which can operate the acquired business as a division, with the obligation on the price payable only out of the assets or profit of the acquired business.

Organizations other than churches may still achieve something like the same results, although with considerable change in form and scope, where the price can be funded out of profits over a period which does not exceed the time limitations of section $514 .{ }^{88} \mathrm{~A}$ transaction of this nature is discussed in Revenue Ruhing 54-420, 99 which involved the following factual situation: A foundation formed for charitable purposes proposed to acquire a business from its shareholders in exchange for the foundation's note. The business so acquired was to be dissolved and the current assets sold to an operating company, and the balance of the assets were to be leased and licensed to the same operating company, at rentals of 80 percent of annual net profits. An initial payment to the seller was to be made from the assets received by the foundation on dissolution of the business acquired, and the balance paid out of the rentals received. The foundation's note would be secured by a mortgage on the assets leased to the operating company and by a pledge of the rentals to be received. The foundation was not to be personally liable for any portion of the price agreed to be paid.

Thus, although the mechanics had changed somewhat, the basic idea remained the same. The operating company replaced the feeder. In order to eliminate the tax on the income of the feeder, virtually all of this income was to be paid out to the exempt organization as "rent." The only severe mechanical restriction on the plan is the 5-year limitation on the lease, necessitated by the 1950 amendments which would render rentals from a longer-term lease subject to income tax, thus leaving the exempt organization with no advantage permitting payment of a ligher price.

\section{Application of the Revenue Bond Statutes}

While it is somewhat presumptuous to attempt any cataloguing of the myriad schemes which can be used in working with the revenue bond statutes, ${ }^{70}$ it will, I believe, be helpful at this point to consider the pure mechan-

65 I.v. REv. CODE OF 1954, § 502.

68 INI. REV. CODE OF 1954, \$§ 511-14.

(i) INT. REv. CODE of 1954, $\$ 511$ (a) (2) (A). Apparently the theory is that one may properly lay up treasures either in (or on behalf of) heaven.

C8 For these purposes, it will suffice to say that the time is 5 years. See INr. REv. Code or $1954, \$ 514(\mathrm{~b})$.

69 1954-2 CrM. Berc. 128. See text at notes $138-45$ infra for a discussion of the ruling.

70 As one example of what can be done, consider the issue by Florence, Alabama, for Stylon Corporation, under which the municipal bonds may be converted into common stock of Siylon. See Always Something New, 44 Moody's Bond Survey 315 (1952). 
ics of the basic ways in which the various bond statutes can be adapted to plans much like those suggested above. It should, however, be emphasized that the inventiveness of the planner is of primary importance here, where the normal is unusual and the exotic is normal.

\section{1. "Industrial Building" Statutes}

The Alabama-type statute, ${ }^{71}$ limited in its application to the financing of buildings, affords fewer opportunities for inventiveness than does the New Mexico statute. It does, however, permit manipulation of the exemptinterest aspect of municipal bonds, and the lease form of financing heretofore engaged in by exempt organizations.

The simplest possible plan would simply substitute as the borrowing medium the tax-exempt bonds of the municipality for the taxable bonds of the business, the contemplated advantage being whatever reduction there might be in the rate of interest that would have to be paid. ${ }^{72}$ Mechanically, such a plan would be effected through the municipality's issuing its revenue bonds to the public ${ }^{73}$ in the amount necessary for financing the construction of the facility, followed by a sale of the facility, once constructed, to the business, on terms identical to the repayment provisions of the bonds. The business making payments to the city would obtain a deduction for the interest paid; the city would have no taxable income because of its general immunity; and the interest received by the bondholders would be exempt as municipal bond interest. As was illustrated above, the potential tax saving from financing in this fashion would amount to about onehalf of the reduction in interest rate required to be paid. ${ }^{74}$

The advantages of tax-exempt interest rates could easily be, and normally are, ${ }^{75}$ combined with the advantages of "lease" type financing. Mechanically, the only difference would lie in the municipality's "leasing" the facility to the business, rather than selling. As was explained above, the potential savings under this form of financing would be an additional $\$ 15,-$

71 See note 24 supra.

72 See text at notes $33-42$ supra.

73 By the term "public," as used herein, is meant investors who have no prior contact with the business. This would include both a general distribution of the bonds, and a sale of the entire issue to one institutional investor. It should also he noted that an additional advantage in such distributions is the general exemption of municipal bond issues from securities regulation and state "Blue Sky" requirements. See Securities Act of 1933, §3(a) (2), 48 Stat. 76, as amended, 48 Stat. 906 (1934), 15 U.S.C. \$77c(a) (2) (1958); Note, 66 HaRv. L. REv. 898, 906 n.86 (1953).

74 See note 42 supra.

i5 See Comment, Legal Limitations On Public Inducements to Industrial Location, 59 CoLusr. L. REv. 618, 630 n.n.95-96 (1959), setting forth facts from those cases in which mention has been made of this aspect of the transactions in other States. See also Jones, Federal Incone Tax Deductions of BAWI Leasehold Payments, 30 Miss. L.J. 10 (1958). Insofar as can be determined, all of the transactions so far set up under the New Mexico statute have been cast in the "lease" form. See text at notes 91-96 infra. 
000 annually, per million dollars of value ${ }^{76}$ assuming the hypothetical facts there used, and the inclusion of a "recapture" clause in the lease.

Both of these devices are essentially measures for reducing the cost of financing construction of the facility. While it is the federal income tax law which creates the advantages, the tax aspects are not significant per se. However, municipal revenue bonds can be employed as pure tax-saving devices, to convert income taxable at ordinary income rates into tax-exempt income. The theory can be demonstrated by a nonsense illustration, based upon a $\$ 1,000,000$ facility.

Assume that the business itself constructs the facility to be used, and then sells the facility to the municipality for 6-percent revenue bonds in the face amount of $\$ 1,000,000$ and immediately repurchases for the same price, payable on precisely the same terms as the bonds. Over the 20-year period, the business would pay to the municipality a total of $\$ 1,630,000,77$ and would receive payments on the bonds in precisely the same amount. Thus, absent the tax laws, the effect of the transaction would be a wash. But the interest of $\$ 630,000$ paid to the municipality would have a value of $\$ 315,000$ as a deduction for tax purposes, while the same interest, being repaid by the municipality on the bonds, would be tax exempt, thus increasing after-tax income by $\$ 315,000$ without any real economic change.

Obviously, a sale and repurchase of such bald simplicity would have some difficulty in the courts. It seems unquestionable but that the claimed interest deduction would be attacked. ${ }^{78}$ On the other hand, if the re-acquisition took the form of a lease-back, then there would be greater substance to the transaction, since it would become indistinguishable from the commercial "sale and lease-back" financing except that bonds, mstead of cash, would have been received on the sale. Further, the business would receive the added advantages of the greater deductions available under lease-back financing, thus increasing the total gain on the transaction.

Variations of these techniques, even less vulnerable to attack as a sham, can be effected in the case of a closely held corporation, the owner or owners of which wish to get cash out of the business. ${ }^{79}$ A typical plan might call for the construction of the building by the owners of the business, followed by its sale to the municipahty for revenue bonds, and a resale, or a leasing, from the municipality to the business. ${ }^{80}$ Either method would give the business deductions (either for rent, or for interest and depreciation)

78 See text at note 53 supra.

77 See note 34 supra.

78 See, e.g., the inglorious fate of the latest interest "gimmick." E. D. Goodstein, 30 T.C. 1178 (1958), aff'd, 267 F.2d 127 (1st Cir. 1959); A. Mr. Sonnabend, 17 CCH Tax Ct. Mem. 882 (1958), af'd, 267 F.2d 319 (1st Cir. 1959).

79 Of course, substantially similar transactions without interposition of a municipality are commonplace in the case of closely held corporations, in which the owners hold out certain of the productive facilitics, and rent them to the business. See, e.g., Attick, The Family Business, N.Y.U. 16Tr INst. OX FED. TAX 755, 758 (1958).

80 See State ex rel. Beck v. City of York, $16+$ Neb. 223, 82 N.W.2d 269 (1957). 
for money paid by the business to the municipality and immediately repaid by the municipality to the owners as tax-exempt interest and return of capital. Assuming that the owners are in a 60-percent bracket, the net advantage of employing the municipality as a vehicle for the transaction, rather than entering into it directly with the business, could be $\$ 138,000$ on a "lease" basis..

Nor is it essential that the business attempting such a plan be a closely held one. A similar technique could be employed by a publicly held corporation, through forming a subsidiary to operate the new facility, and having the parent corporation furnish the building (or the funds for the building) to the municipality for revenue bonds.

\section{2. "Business" Plans Under the New Mexico Statute}

In considering the potential uses of the New Mexico statute, it is well to keep in mind the basic elements of the "building" plans potentially available under the Alabama-type statute. As can be seen from the foregoing section, the only requisite to use of any of the "building" plans is a willingness to operate a new facility in a municipality in a state having an authorizing statute permitting issuance of industrial building revenue bonds.

Under the New Mexcio statute there must be a new entity in the picture-the "New Mexico corporation" "by or for" which the existing business is acquired. ${ }^{82}$ Pretermitting for the moment the problems of statutory construction raised by the definitional clause in the New Mexico statute, ${ }^{83}$ the general outline of all plans thereunder can be stated to be the following: (1) sale of an existing business located outside New Mexico to the municipality for bonds or cash obtained through the issuance of bonds; (2) relocation of the business so acquired in or near the municipality issuing the bonds; (3) disposal by the municipality of the business so acquired to a New Mexico corporation; (4) payments by the New Mexico corporation to the municipality, which payments are then used to service the bonds issued in connection with the acquisition of the business.

81 The corporation's situation would be the same as if dealing directly witb the owner. On a 20-year lease, the owner, were he leasing directly, would report the entire amount received, $\$ 1,630.000$, as rental income. From this he would deduct $\$ 400,000$ depreciation (one-half the building's value, over half its life) for net income of $\$ 1,230,000$, the tax on which (assuming a $60 \%$ bracket) would be $\$ 738,000$; leaving after-tax income of $\$ 1,630,000$ less $\$ 738,000$, or $\$ 892,000$. In addition, assuming cconomic depreciation to be on a straight line (see note 54 supra) be would regain possession of a facility worth $\$ 600,000$, giving him net values received over the 20 years of $\$ 892,000$ plus $\$ 600,000$, or $\$ 1,492,000$. Interposing the municipality, the owner would realize on sale to the city tax-free and tax-cxcmpt receipts of $\$ 1,630,000$, making a gain of $\$ 1,630,000$ less $\$ 1,492,000$, or $\$ 138,000$. It should be noted, however, that in the lease by the municipality to the business a "recapture" clause would be necessary to insure the business' getting the facility at the end of the term, whereas if the owner leases direct, no such clause would be required, since the owner would probably prefer to retain possession. See text at note 56 supra. 
As a starting point, let us assume that Acmex Corporation is a New Miexico corporation interested in the acquisition of new businesses. The uses to which it could put the New Mexico statute are obvious, and quite similar to the "building" plans discussed above. The simplest plan would be to have the municipality make a public issue of its revenue bonds to acquire the cash to effect an acquisition of a business located outside the State. The business, once so acquired, would be sold by the municipality to Acmex on repayment terms identical to those of the bonds. ${ }^{84}$ For the seller of the business, the existence of the statute would be immaterial, since he would receive nothing but cash; for Acmex the statute would provide a means whereby it could obtain the funds to effect: the purchase at a reduced rate of interest.

Alternatively, the municipality could offer the seller bonds in lieu of cash, or a combination of bonds and cash. In theory, at least, such bonds should be more attractive than a note from Acmex, by virtue of the taxexempt nature of the interest payable on the deferred portion of the price. If, for example, the purchase price for the business were $\$ 1,000,000$, payable over 10 years in equal instalments with interest on the deferred principal amount at 6 percent, and the seller was in a 60 -percent bracket, there would be an advantage of $\$ 198,000$ in taking the tax-exempt bonds. ${ }^{85}$ Or, to approach it from the other side, the seller could be given precisely the same after-tax income through the use of 2.4 percent municipal bonds to

${ }^{84}$ This is subject to two qualifications. First, the total amounts paid by the acquiring corporation will slightly exceed the amounts needed to service the bonds, inasmuch as the municipality will ordinarily assess some service charge for handling the payments. Second, it is not essential that the moneys as received by the municipality be disbursed immediately to the holders of the bonds. It might, for instance, be desirable to have a sinking fund used to accumulate amounts necessary for ultimate retirement of the bonds. This would permit the holders to enjoy the unusually high interest on the honds for a greater time. With such a fund, the total payments by the municipality to the holders of the bonds would be slightly more than the municipality's total receipts from the business, by virtue of the earning capacity of the fund.

85 Interest paid during the period would amount to $\$ 330,000[.06 \times(1 / 10 \times 1,000,000) \times$ $\frac{10 \times 11}{2}$. The tax on this would be $.60 \times 330,000$, or $\$ 198,000$, the entire amount of which would be avoided were the bonds exempt.

The question most commonly raised in connection with this computation is, why doesn't the seller of the business take cash and invest it in municipal honds? The answer is two-fold: In the first place, the industrial revenue bonds bear an interest rate far higher than normally available, one issue being reputed to bear $9 \%$. In the second place, a seller simply could not obtain so much cash for investing as he can by exchanging his business for bonds. As pointed out in the text following note 61 supra, one can normally obtain a much better price for a business where the entire amount is payable out of profits of the business than he can obtain on a cash or firm-price basis. The revenue bonds afford the seller the benefits of a high interest investment, in some ways superior to cash, and afford the purchaser the benefits of a payment out of profits.

Further, use of the bonds permits deferral of the capital-gains tax (see text at, and notes following, note 147 infra) so that the entire price can be invested, rather than the price less $25 \%$ of the gain. 
evidence the price, ${ }^{85}$ in which case the benefit of the $\$ 198,000$ saving would accrue to Acmex. Further, the price could be reduced through the use of higher interest bonds on a smaller principal amount. For instance, if the seller's basis in the business were $\$ 120,000$, he could be given $\$ 816,666.67$ of 6-percent bonds, and realize the same after-tax income as would have been obtained on $\$ 1,000,000$ of 6-percent non-exempt notes from Acmex. ${ }^{87}$ Obviously, in the negotiations over price there would be a compromise between the total advantage going to either party.

All of these transactions have assumed that the municipality would resell the business being acquired. Under the statute, there is a prohibition upon the city's actually operating a business; ${ }^{88}$ there is no requirement, however, that disposal be on a sale basis. There is, in fact, specific statutory authority for a "leasing" of projects. ${ }^{89}$ This suggests the possibility of employing a plan similar to that set forth in Revenue Ruling 54-420, ${ }^{90}$ for the purpose of increasing the price that can be paid for the business.

Mechanically, the transaction with the municipality would parallel that of the transaction with the foundation. The business would be sold to the municipality, and then leased by the municipality to an operating company for "rentals" of $80-90$ percent of net profits before taxes, thereby effectively eliminating the tax on the operating entity. The municipality would receive these rentals without liability for tax, and pay the entire amount to the sellers of the business in retirement of the bonds, and satisfaction of the interest obligation on the bonds. The only differences between these transactions and the "sale to charity" schemes lie in the municipality's not being hampered by the "business lease" rules now applicable to exempt organizations, ${ }^{91}$ and its ability to further enhance the transaction through use of the exempt interest feature.

A striking example of the consequences of such a plan is afforded by

80 Being the seller's after-tax retention of income $(1.00-.60=.40)$ times the interest rate, or .40 times .06 .

87 Let $P$ be the principal amount. The desired after-tax proceeds are to be tbe same as would have been received under a transaction using taxable evidences of indebtedness, or $\$ 1,000,000$ less capital gains tax, plus interest, less taxes on interest. With a basis of $\$ 120,000$, the capital gains tax would be $\$ 220,000$. Net interest retained after taxes is $\$ 132,000(.40 \times$ $330,000)$, making total retention of $\$ 912,000(1,000,000-220,000+132,000)$. With tax-free interest, the net retention will be $.06 \times \frac{10 \times 11}{2} \times \frac{P}{10}$ or $.33 P$. The after-tax value of the principal which is subject to capital gains tax will be $P-.25[P-120,000$ (the basis) ], or $.75 P+30,000$. In formula, then:

$$
\begin{gathered}
912,000=.75 P+30,000+.33 P \\
882,000=1.08 P \\
P=816,666.67
\end{gathered}
$$

88 Actually, two of them. See N.M. Stat. ANs. $\$ \$ 14-41-32,-33$ (Supp. 1959).

80 N.M. Stat. ANx. $\$ 14-41-33$ (1) (Supp. 1959), and see N.M. Stat. ANx. \$14-41-36 (Supp. 1959).

80 See text at note 69 supra.

91 See note 66 supra. 
the transaction described in a prospectus issued by American Industrial Financial Co., in connection with one of the Village of Deming revenue bond issues. The example there set forth is of a business with before-tax earnings of $\$ 250,000$ per year, with a maximum profit potential before taxes of $\$ 300,000$. The acquisition is to be made at a price of $\$ 2,012,000$, evidenced by 7-percent municipal bonds. The anticipated pay-out period is 15 years.

Were such a transaction to be entered into with a private corporation, the total amount that could 'pe paid out of profits (assuming they remain constant) after deduction of service costs would be $\$ 1,773,500 .^{92}$ From this there would be deducted capital-gains tax, and tax on the interest on the deferred installments of the price, which would leave a net to the sellers, under the facts set forth in the prospectus, of about $\$ 1,163,500 .^{93} \mathrm{By}$ using the "leasing" device for the disposal by the municipality, the total amounts payable are doubled, to $\$ 3,547,000$, on which, absent the exempt-interest feature, the retention would be $\$ 2,383,060,{ }^{94}$ an increase of $\$ 1,219,560$. Because of the exempt feature of the interest, the retention is increased to $\$ 2,997,100,^{95}$ an additional $\$ 614,040 .{ }^{.6}$

It should be noted that these figures are slightly incomplete. The deduction of the rentals payments must, to some extent, be offset by the loss of deductions for depreciation and amortization. ${ }^{97}$ To the extent that the price paid for the business represents the value of depreciable or amortizable

92 One-half of the amount estimated to be payable out of profits under the transaction described in the prospectus.

${ }^{93}$ The basis in the business being sold is negligible, and the sellers are stated to be in a $40 \%$ bracket.

04 The prospectus figures are, as follows: Total interest paid would amount to $\$ 1,535,100$, and the tax rate of the sellers is stated to be $40 \%$. Adding $\$ 921,060(.60 \times 1,535,100)$ to the amounts payable as price subject to capital-gains tax (a net of $\$ 1,462,000$ ) gives a total retention of $\$ 2,383,060$. The prospectus seems to include in its computations service costs and depreciation.

95 As computed in the prospectus.

${ }^{98}$ This benefit is the value of $.40 \times 1,535,100$.

97 The prospectus contains no mention of the problems of depreciation, discussed in the text following tbis note. Presumably the matter was considered, inasmuch as the opinion appended to the statement of facts suggests that loss of the rental deduction would not be fatal by virtue of the alternative deduction for depreciable and amortizable assets. This opinion, however, appears to have been drafted in connection with a different transaction.

The statute implies that the "rentals" paid under a leasing arrangement be suficicnt to provide for a reserve comparable to one for depreciation, or, alternatively, that an undertaking to make comparable provision be taken from the lessee. N.M. Stat. ANs. \$14-41-36 (Supp. 1959). If, as would seem reasonable, the profit figure set forth in the prospectus has. heen computed after deduction for depreciation, than it may be that the rents to be charged are to be increased by the amount of that deduction. This, however, is nowhere explicit in the prospectus. If it is contemplated tbat the depreciation reserves will be accumulated by the lessee, the accumulation would not be deductible, the deduction belonging to the city.

From a practical standpoint, if the depreciation factor is to be taken care of through increased rentals, then the business will, in effect, be liquidating itsclf. It can only obtain funds for new asset acquisitions through additional transactions with the municipality, involving additional rentals. 
assets, deductions can be taken. As the relative value of assets of this type to the total value of the business increases, the advantages of acquisition through "rental" payments will decrease. At the same time, however, the entire general approach of measuring price in terms of profits becomes less and less realistic. ${ }^{98}$ Consequently, the type of business for which this form of acquisition is best suited will be one with a high proportion of nonamortizable intangibles to total values-in short, one with high "goodwill" in the generic sense of that term.

From the standpoint of the existing business outside the State of New Mexico, all of these plans present one rather substantial difficulty: they appear to contemplate a relinquishment of the owner's control in favor of some third party. Of course, under most plans, this will not be immediately true, since there are generally provisions included for a continuation of control by the sellers until the price has been paid in full. ${ }^{99}$ But the eventual aim of the plans is a change of ownership of the business. If the statute is to be generally useful, it must have application to businessmen who are not interested in disposing of their businesses. Such applications appear to be possible, subject only to the condition that the result be the relocation of a business, or division of a business, in New Mexico, as required by the statute. ${ }^{100}$

To illustrate these applications, assume that Acme Manufacturing is a California corporation, engaged in the manufacture and nation-wide distribution of widgets. Acme is interested in diversification and expansion of its operations.

The most obvious application of the New Mexico statute would be as an aid to the acquistion by Acme of new businesses which could be relocated in New Mexico. Since Acme is a California corporation, however, it could not itself be the acquiring corporation. Rather, there would have to be a reincorporation of Acme as a New Mexico corporation, after which it could employ any of the techniques discussed above for acquiring new businesses. More practically, Acme could form a new New Mexico corporation-Acmex - either as a subsidiary or a "brother" corporation, and have this new corporation handle the acquisitions. ${ }^{101}$

88 To the extent that the price is paid for tangible assets, it would be based, presumably; upon the market value of those assets, which, although reflecting in a general way the potential earning capacity of the property over its useful life, would not necessarily be related sufficiently dircetly to earning potential to warrant computation of a price through capitalization of earnings.

${ }^{89}$ But sec text following note 144 infra.

100 The statute requires that the acquisition be "by or for" a New Mexico corporation. N.M. StaT. ANiN. \$14-41-31 (Supp. 1959).

101 There are certain drawbacks to incorporation in New Mexico, as a result of quirks in its corporate law, and lack of authoritative court pronouncements on some ambiguities in the statutes. See, e.g., N.M. STAT. ANv. \$ 51-2-8 (1953) restricting the existence to 100 years. For this reason, creation of a new corporation rather than reincorporation would seem preferable. 
From this plan, it is but a short step to the possiblity of using Acmex to acquire part or all of the operations of Acme in exchange for bonds. For instance, if it were feasible to relocate a division of Acme of New Mexico, Acmex could acquire this division through the municipality. ${ }^{102}$ One might note that the interesting result of this would be the deduction by Acmex of amounts paid, through the city, to Acme, as tax-exempt interest and repayment of principal.

Finally, there is the possibility of acquiring the entire operation of Acme. The owners of Acme would form Acmex in New Mexico. Then they would exchange their stock in Acme for municipal bonds. The municipality would dissolve the business, and lease or sell it to Acmex. Then, if a "leasing technique" were used, as payments were made by Acmex to the municipality, there would be deductions for the full amount of the payments, and the owners, as holders of bonds, would receive these payments as taxexempt interest and payments of principal. And thus we have, mirabile dictu, converted the income of the business into deductible payments which are tax exempt to the owners of the business.

\section{III}

THE CORPORATE AND TAX PROBLEMS INVOLVED

With such exciting possibilities present, it would seem strange that there has not been a veritable gold rush of American business to the State of New Mexico. The reasons for the reluctance to jump on the westbound wagon train (or eastbound, depending on one's point of origin) are not far to be sought.

\section{A. Non-Tax Problems}

While the purported benefits of the statute arise primarily from manipulation of the tax law, and hence the acid test of its effectiveness will depend upon its efficacy in achieving the promised tax results, it is important to note that there are many as yet unsolved non-tax problems in connection with the New Mexico statute, most of which arise from an apparent failure to consider certain practical questions in drafting the statute.

\section{Interpretative Problems}

As was indicated above, ${ }^{103}$ the New Mexico statute is generally spoken of, and treated as, authorizing the acquisition by municipalities of going businesses, these businesses then to be resold to a New Mexico corporation. The definitional clause which purports to make this possible provides that the term "project" comprehends land, buildings, and other improve-

102 See text at notes $103-12$ infra.

103 See text at note 28 supra. 
ments and "the acquisition by or for a New Mexico corporation of the assets or stock of an existing business or corporation located outside the State of New Mexico to be relocated within or near the municipality in the State of New Mexico." Mos Municipalities are then empowered to acquire "projects" located within 15 miles of the limits of the municipality.

The first problem suggested is whether the statute may be used as a simple "building" statute, or whether it must be used only as a "business" statute. The obvious answer to this question would be that the statute could be used either fashion. Especially is this true in view of its ancestry. ${ }^{105}$ The difficulty lies in the use of the conjunctive "and" in the definitional clause, ${ }^{108}$ which could call for restricting the statute to "business" plans. However, it would appear that there is no real difficulty in construing the clause disjunctively, and that from the standpoint of flexibility this would certainly be the preferable construction.

Assuming, though, that the statute is to be used as a "business" statute, let us consider the mechanics of the transaction to be entered into where, for instance, Acmex is acquiring a Delaware corporation, Star Manufacturing. Who must acquire what? Although the first impulse is to assume that the municipality will make the acquisition of the business, it will be noted that the municipality is empowered only to acquire "projects," not businesses. ${ }^{107}$ And a "project" includes the acquisition "by or for" a New Mexico corporation of the assets or stock of a going business. Semantically, it is obviously impossible for the municipality to "acquire" the "acquisition" of anything, so that some judicial inventiveness is going to be required in fathoming the legislative intent.

The use of the term "acquisition" in the definition of "project" seems to suggest a fait accompli at the time the municipality appears on the scene, in which case the New Mexico corporation must be the instrumentality making the acquisition. Further support for this position is found in the statutory provision authorizing acquisition of "projects" which provides that the municipality may acquire "projects" "which shall be located within this state and may be located ...."108 This language is to be contrasted with the definitional provision which speaks of "to be relocated within or near the municipality ...." Again, evidence of a fait accompli as to the acquisition and relocation before the municipality may act.

But if the statute is construed in this fashion, then the only method for getting the bonds into the hands of the seller would seem to be through

$10+$ See text at note 29 supra.

100 See text at notes $20-26$ supra.

100 See text at note 29 supra.

107 N3. Stat. ANe. \$ 14-41-33 (Supp. 1959).

$100 \mathrm{Ib}$ id. 
Acmex's obtaining the bonds by giving its note to the municipality, and then turning the bonds over to the sellers in exchange for the business. This would have the unfortunate effect of depriving the seller of the possibility of using the installment-gains method of reporting the sale, ${ }^{100}$ and depriving the acquiring corporation of using the "leasing" techniques in connection with the repayment of its obligation to the municipality. If, then, the statute is to have full effectiveness, it is imperative that it be construed so as to permit the municipality to make the acquisition of the business being sold.

The next problem is the determination of whether that which is being acquired constitutes a business of the type eligible under the definition of "project" and the provisions authorizing the municipality to act. Both of these clauses speak in terms of the "location" or "relocation" of the "project"- which latter term we have re-defined as "the entire going business." If the business consists simply of a manufacturing plant, with no distribution system, then this presents no substantial difficulty. But if the business is of any size at all, it is quite likely that it will have operations that cannot be confined to any single location. What portion of the "entire going business" must be "relocated" near the municipality in order to permit acquisition under the statute?

The reverse of this question is alc $n$ unresolved. May less than an entire business be acquired, as, for instance, the acquisition by Acmex of a division of Acme Manufacturing. The statute, it will be recalled, speaks in terms of "the assets or stock of an existing business or corporation . ..." And what of the acquisition of less than all of the stock of a corporation?

These are obviously problems that were overlooked in the adaptation of the Alabama statute to this new use. There is simply no hint of a solution in the language of the statute. Again it would seem that a reasonable construction should be adopted, and that the reasonable construction would be that so long as the purpose of the statute-attracting payrolls to New Mexico-is satisfied, the definitional problems are to be resolved in favor of whatever plan is devised. But even this approach creates difficulties. What of assembly plants in otber areas, which on a composite oasis do, perhaps, half of the total manufacturing? Or what of businesses that are primarily service industries, in which the manufacturing is but a small part of the overall picture, and the value of the payroll in any one location is negligible? It is most unfortunate that these problems were overlooked in enactment of the statute, for they render the law questionable for ail save the simplest of operational structures.

Unfortunately, the problem of amendment of the statute is beclouded

102 Since, in that event. the "evidences of indebtedness" would not be those of the purchaser See text at notes 149-52 in/ra 
somewhat by fears that there might be a new attack on its constitutionality. The present law has been before the New Mexico Supreme Court. It was originally declared unconstitutional by a 5-0 vote. ${ }^{110}$ Subsequently, this opinion was vacated, and the statute was held constitutional by a 3-2 vote. ${ }^{111}$ In view of the extensive reliance upon the decision upholding constitutionality of the act, it would seem, however, that the court would be most unlikely to reverse itself in passing on clarifying amendments essential to intelligible construction of the law. ${ }^{12}$

\section{Availability of Exemption From Local Property Taxes}

One question as to which there is considerable doubt is the efficacy of "lease" arrangements for avoiding property taxes on the business being acquired. The statute provides:

110 Village of Deming v. Hosdreg $\mathrm{Co}_{2} 24$ U.S.L. WEEx 2265 (N.M. Dec. 20, 1955) (vacated), 40 MINx. L. REv. 681 (1956).

111 village of Deming v. Hosdreg Co., 62 N.M. 18, 303 P.2d 920 (1956). The primary attack was based upon art. IX, $\$ 14$ of the New Mexico Constitution, which in part provides: "Ncither the State, or any ... municipality, ... shall directly or indirectly lend or pledge its credit, or make any donation to or in aid of any person, association or public or private corporation, or in aid of any private enterprise for the construction of any railsoads; provided, nothing herein shall be construed to prohibit the State or any ... municipality from making provision for the care and maintenance of sick and indigent persons."

The decision upholding the constitutionality of the statute is in accord with the position of most of the other States with industrial revenue bond statutes. Newberry v. City of Andalusia, 257 Ala. 49, 57 So. 2d 629 (1952); Faulconer v. City of Danville, 313 Ky. 468, 232 S.W.2d 80 (1950); Albritton v. City of Winona, 181 Miss. 75, 178 So. 799 (1938); Holly v. City of Elizabethton, 193 Tenn. 46, 241 S.W.2d 1001 (1951). Contra, State ex rel. Beck v. City of York, 164 Neb. 223, 82 N.W.2d 269 (1957). See Note, Legal Limilations on Public Inducements to Industrial Location, 59 Coluar. L. Rev. 618, 630-34 (1959) ; Note, 66 HARv. L. REv. 898, 90004 (1953).

112 It should be noted, however, that the Hosdreg decision is not a model of elarity. The issue is posed as being, "Does the giving of aid to a private enterprise, here shown, amount to the making of a donation within the prohibition of Const. Art. IX, $\$ 14$ ?" Village of Deming v. Hosdreg Co., szipra note 111, at 27, 303 P.2d at 925-26. (Emphasis added.) Then the decision scems to turn upon the fact that aid to the corporation through the revenue bond device is not a donation.

What is left of this after State v. Hannah, 63 N.M. 110, 314 P.2d 714 (1957), is diffeult to determine. In that case the Hosdreg decision was adverted to in the following language: "The basis of the majority opinion was that such advantages . id aid as the lessors [lessees] would receive, and who incidentally were granted a very favorable option to purchase or extend the lease by a contract held to be valid, was justified as a public purpose inasmuch as it would attract industry to the State and relieve distressed communities when there were large numbers of unemployed." Id. at 118,314 P.2d at 720 .

No page citation was offered to support this statement. It would seem unlikely that reference was intended to this passage in Hosdreg: "What we hold is that there is not here present on the record before us a 'donation to or an aid of any ... private corporation' in violation of Const. Art. IX, $\S 14$ or the 'giving of aid to private enterprise,' even if the latter phrase should be read into the questioned proviso as a matter of construction. This, we think, should not be clone, save only where the 'aid or benefit' disclosed, by reason of its nature and the circumstances surrounding it, take on character as a donation in substance and effect." Village of Deming v. Hosdreg Co., 62 N.M. 18, 28, 303 P.2d 920, 927 (1956). 
The bonds authorized by this Act and the income from said bonds, all mortgages or other security instruments executed as security for said bonds, all lease agreements made pursuant to the provisions hereof, and revenue derived from any lease or sale by the municipality thereof shall be exempt from all taxation by the State of New Mexico or any subdivision thereof. ${ }^{113}$

This language, which is certainly at best ambiguous on the point, and the fact that title to "leased" property is ostensibly in the municipality, have been said by some to exempt the property owned by the business being acquired from property taxes. ${ }^{11}$ In the case upholding the constitutionality of the statute, ${ }^{115}$ however, the court noted this argument of counsel:

The provision is clear and extends only to the municipality. Of course, under a lease arrangement whereby the city owns land, no ad valorem laxes would be imposed, but then does not that apply to all other municipal projects, such as airports, recreational areas and other community and civic non-profit sponsored activities? ${ }^{110}$

In response, the court stated:

There is nothing in the Act exempting the defendant [the operating lessee of the property] from ad valorem taxes on its leasehold interest, raw materials, stock and equipment. ${ }^{117}$

It is clear that the court suggests that the lessee corporation is subject to a tax on its leasehold interest in whatever properties are ostensibly owned by the municipality. This statement should be read in conjunction with a subsequent decision in which it was held that the leasehold interes $t$ of one holding property on lease from the United States Government mus/ be taxed even though there is wo specific statute authorizing a tax upon such interests, in view of the constitutional mandate to equal taxation of all property not specifically exempted. ${ }^{118}$

As a practical matter, this question is not likely to becom': critical. The City of Albuquerque has indicated its intention to collect prsperty taxes no matter what the state of the law may be, through insisting upon an undertaking to this effect from any business considering the use of the revenue bond law and the Albuquerque enabling ordinance. In certain other municipalities the assessment policies are so inadequate that payment of any taxes is unlikely.

113 N.MI. STAт. Axs. \$14-41-41 (Supp. 1959) (entitled "Exemption from Taxation").

11 See Note, 40 Mns. L. REv. 681, 684 (1950́); Notc, Legal Limilations on Public Inducemerits to Industrial Location, 59 ColvM. L. REv. J18, 644 (1959). Sie also Prospectus, Prepared by American Industrial Financial Co. Inc., p. .

I15 Village of Deming v. Hosdreg Co., 62 N.M. 18303 P.2d 920 (1956).

116 Id. at 34,303 P.2d at 930-31. (Emphasis acide 1.)

117 lbid.

118 Kirtland Heights, Inc. v. Board of County Comm'rs, 64 N.M. :79, 326 P.2d 672 (193.3). 


\section{Salcability of the Bonds}

The most substantial practical problem in connection with the use of the New Mexico statute lies in the very discouraging unsaleability of the bonds. The seller of a business who accepts bonds in return for his business must accept the fact that for several years at least he is the possessor of a most frozen asset-albeit a most productive one.

To date, insofar as can be determined, there have been only two attempts at public sale of bonds issued under the New Mexico statute. One is apparently a primary offering, by the City of Carlsbad. The prospectus indicates that the city has not yet entered into a firm contract with any business to be acquired, but rather, that the funds obtained will be applied at the direction of the city's financial consultants. The bonds consist of one series of 7-percent 20-year bonds, and another of 6-percent 30-year bonds, with both interest and principal of the 6-percent issue pegged to the National Consumer Price Index. The other altempted public distribution is apparently a secondary offering of one of the Village of Deming issues. Conversations with independent bond houses and municipal men in the larger firms indicates that distribution through normal channels is virtually impossible.

\section{B. Tax Problems}

In determining whether or not a particular plan is workable, however, the basic issues are not too likely to be the non-tax problems. Rather, since the benefits of the statute are predicated upon obtaining certain tax results, it is with the effectiveness of the plan under the federal income tax laws that the planner will be primarily concerned. As might be anticipated, the magnilude of the tax problems varies directly with the attractiveness of the promised benefits.

\section{Tax-Exempt Status of Intcrest Paid by the Municipality'12}

For sheer excitement, few experiences can equal that of suggesting to a municipal official that the interest paid on industrial revenue bonds should not be considered exempt from federal income taxes. Amidst dark mutterings of camels' noses and tents, explanations will be forthcoming satisfying all municipal officiais that the exemption of interest on all municipal bonds from federal texation is a very cornerstone of our federal system.

The Internal Revenue Service has, to date, not seen fit to enter the lists

"10 Ser exenerally Irs. Rzv. Copr. or 1954. 103 (a)(1). Whatever constitutional merit there may be to the exemption is founded upon the decision in Pollock v. Farmers' Loan \& Trust Co., 157 US 129 (1895), af'd on rehrarink, 158 U.S. 601 (1895). The vallidit of the anguments underlying the exemption are not involved here. The writer of Note, Legal Limila. trons on Public Inducements to Industrial Location, 59 Coluss. L. Rzv. 618 (3959), has gath. cred many of the sources. Id, at 636-38. 
against the municipal officials. There have been several rulings in connection with building-type statutes in which the exempt nature of the interest has been passed upon favorably, ${ }^{120}$ and despite occasional legislative attempts to alter the rule, ${ }^{121}$ it would seem probable that no change will be made in this rule. The only possible attack upon this favored position of the payments made by the municipality will in all proiubility not be directed towards the interest on the bonds as such but rather towards the nature of the transaction, and the instruments used to evidence it. $A s$ is pointed out below, this type of attack might be successful. ${ }^{122}$

\section{Tox-Excmpt Sichus of Amounts Paid to the City}

One of the other essential ingredients in all of the plans for use of the revenue bonds is the municipal immunity from taxation upon reccipts of every nature. For obvious political and practical reasons, this is unquestionably the strongest point in the entire planning picture, and it can safely be assumed that this aspect will be free from attack. ${ }^{20}$

\section{Deductibility of Payments to the Municipality}

There are essentially two methods by which the municipality can dispose of the property acquired under the revenue bond statutes-either by sale or by lease. ${ }^{124}$ Where the "project" is sold by the municipality, the portion of the payment attributable to principal would be capitalizable, and recoverable only through depreciation, amortization, or as an offset agninst future gains from resale. ${ }^{123}$ There would seem little doubt, however, but that the interest element of the payments would be deductible as paid to the city, except in those cases in which the holders of the bonds were also the owners of the business, in which event it is conceivable that a "sham" attack might be tried. ${ }^{20}$ So long, however, as the business itself does not hold the bonds, it would seem that the deduction would be safe.

On the other hand, where the property is leased, rather than sold, a bost of problems can arise. First, of course, in order to be deductible, the renta/s must be "reasonable." This is obviously a question of fact, discussion oi which is not particularly fruitful. Certainly if rentals are tied to profits, and especially where they represent a substantial portion of the profits, there will be difficulties. ${ }^{127}$

120 Brgant v. Commissioner, 11 I F.2d 9 (9th Clr. 1910); Rev. Rul. 57-187, 1957-1 Cus. Busl. 65: Rev. Rul. St-106, 295+1 Cux. BuLz. 28.

iz) See the sources gathered in Note, supra note 119, at 637.

122 See text at nates $137-45$ infro.

120 See dole 43 supro.

124 NM. Stat. Ary. 14-1-33 (Supp. 1959). It should be noted, bowever, that the statute also 2uthorize "other disposition" See note $128 \mathrm{~m} / \mathrm{ro}$.

123 Sec text at notes 46-51 supra.

12e See text at note 78 supra.

27 The difficulties of justifying reatals ranging from 80 to $100 \%$ of profits are considered so obvious by most writers as not to bear discussion. See Alexander, The Use of Founda- 
Second, the rentals, to be deductible as such, must be "rentals." In this connection, the first attack upon a business plan might be based upon an argument that one could hardly "lease" an entire business. This would seem to do no more than illustrate that the choice of titles might be more descriptive. ${ }^{238}$

The real problem lies in the very strong possibility that the so-called rentals will be characterized as being in fact payments for the acquisition of a capital asset, which must be capitalized and recovered through depreciation or amortization, if at all. ${ }^{120}$

As was pointed out above, the difficulty in any "lease" form of financing lies in the fact that the "rentals," although of the same amount as mortgage payments, entille the payor to pussession und use of the property only for so long as they are made. ${ }^{30}$ Under a mortgage or conditional sale, title to the property will ultimately reside in the payor; under a "lease" it will revest in the payee at the end of the term. Where a building is involved, it is frequentiy the case that the present worth of the value of the property to be lost at the end of the pay-out period is not equal to the present worth of the nceelernted and increased deductions made possible by lease finaneing, so that the "lessee" is willing to forego the right to permanent possession and use. ${ }^{23}$ But in the case of a "lease" of a business this should not be the case. At the end of the term, the property should be more valuable than

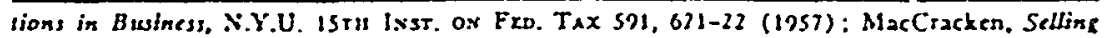

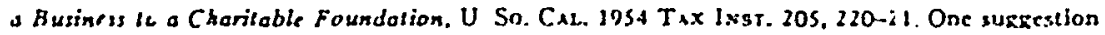
has been made that sinec the iease agrecment is irsponsible for $100 \%$ of the profit of the busines, a rental of $00 \%$ of tbose profite is not excevive. Prospectus. American Industrial Financial Co. Ine.

As b polnted out at note 98 supra. the trasactions in which "Icase" dctices are most fruitful are thowe it whtch the ratlo of nondepreciable non-amortizable ascets to total acets is hishet. This would mean that the mote desrable a leasing format were, the areater the portion of the "Irncals" that would be attributsble to ftesns such as "guodwill," as to the "leasing" of which one has conceptual difficulites See note 128 infro.

12A The conceptual difficuitics of leaving rah, accounts receivabie and accounce payable are troublesome Even more troublesome is the verbalization of the concepts Probably for histoncal reasons, however, all of the Ne Mrxico tranactions as to which any information has been found ate cast as "Iraes" It would seem that a heltes term would be "ogrerating ahreement"

120 The eflect of such a result, of course, is that the efficacy of the "lease" finanacing form Is destroyed. Perhap mote importantly in the prewent contrat, such a result leaver to the acqut ins corpotation the tack of picking up the pieces and idemonstratink the extent to which the allexed rentals involved an irterest element and which price paid for depreciable or amortizable swets Ohviously, the intert would be that the interest to the nequiring cormoration be the came as that paid on the bnnts But where the bonls are bearing o to $9 \%$. and even more so wiste the honds contain "colt of livin:" adjustment elauses (sec lext following note 118 supro). 2 court might choose to reject this fikure and permit a deduction for only a smaller rate ol interest

130 Sre text at notes $54-56$ supra

131 See text at noles $55-56$ supro 
at the beginning of the term. Some form of recapture clause therefore becomes an essential element of the transaction, from the standpoint of the buyer-lessee. ${ }^{32} A$ ind is this "recapture" clause that creates the problems.

The rules regarding recapture clauses are simple: If payments ostensibly made as rentals are in fact payments for the acquisition of a right to possession and use in the future, the payment must be capitalized. ${ }^{133}$ It matters not what form the clause takes-low priced options to purchase (which would be the normal provision in a business acquisition plan), options to renew at low rents, or a lease with high rents for an initial part of the term, followed by nominal rents for the balance of the term. In all of these instances it is fairly clear that payments currently made are, to some extent, intended to confer a future benefit. ${ }^{13+}$ While some courts have displayed a refreshing naiveté in dealing with recapture clauses, ${ }^{123}$ one who depends upon the availability of a deduction for rents in order to permit the funding of bonds received in exchange for a business would be well advised to proceed with the utmost caution. ${ }^{130}$

\section{Validity of the "Business" Type Transaction}

As was suggested above, the real danger to the entire "business" plan lies in the possibility that the transaction between the seller of the business and the municipality may be disregarded. ${ }^{137}$ There is authority for this position in the one ruling and the two cases that have considered similar transactions with charities. They are worthy of full consideration at this point.

Revenue Ruling $54-420,{ }^{\text {ss }}$ it will be recalled, described a sale to a

133 However, in the transaction described in the prospectus issued by American Industrial Finaocial Co., Inc., for the Village of Derning, it is specifically provided that title to the busiress will never pass to the Hosdreg Company, the acquiring corporation. Two 30-year lease terms are provided for, at the conclusion of which the city will bave on its hands a business which the Law forbids it to operate. Presurnably it would be disposed of to the higbest bidder, probably the lessece. Compare MacCracken, Selling a Business 10 a Charitable Foundation, U. So. Caz. 1054 Tax INst. 205, 231.

${ }^{133}$ See Rev. Rul. 55-540, 1955-2 Ciss. Buis. 39; Friedman, Equipment Transactions, N.Y.U. 14TB IxsT. oN Fro. TAx 1427, 1435 (1956).

134 According to Jones, Deductions of BAIVI Leasehold Paymerts, 30 M1ss. L.J. 10 (1958), the Treasury bas already ruled that payments under a typical BAWI lease (containing an extremely low rental provision during the term of the lease extending beyond the pay-out period on the bonds) must be capitalized and amortized over the life of the basic term plus the renewal term, and cannot be currently deducted as rent.

135 See Bruce Veneer \& Pancl Co. v. Commissioner, 232 F.2d 319 (7th Cir. 1956).

136 Essentially, the diffculty is found in the following dilemma: Tha "recapture" clause is sufficienty dangerous to be omited save where essential from an economic point of view. But this very economic necessity, by making it clear that the option to purchase or to renew will be exercised, renders its inclusion dangerous. Thus, "lease" ninancing presents a dileroma for which there is no really good solution, unless there are extrancous business reasons requiring "ise use of this technique.

33isee lext at nole 126 supro.

138 1954-2 Cu24. BuLr. 128. For a statement of the facts, see text at note 69 supra. 
charity almost identical to the typical full-scale "business" plan under the New Mexico statute. The last paragraph of the ruling contains the following language:

Transactions of the type involved in this case also present a serious question as to the essential nature of the agreement entered into by the foundation. It is the position of the Service that in cases of this general nature, the amounts received from the foundation in fulfillment of the terms of the agreement will not be recognized as proceeds from a sale requiring capital gains treatment.

The significance of this last sentence need not be belabored.

The courts have considered the general problems of "sales to charities" in only two cases, both of which involve "feeder" corporations. ${ }^{130}$ In both of them the transaction involved creation of a "feeder" with capital stock of $\$ 1,000$, furnished by or for an exempt organization. The business was then acquired by the "feeder" on notes evidencing the price. The old owners of the business being sold were given management contracts with the "feeder."

In both cases, the Commissioner attacked the transactions as being "reorganizations" instead of sales, and claimed that the amounts paid out to the sellers were in the nature of nondeductible dividends, taxable to the recipients as ordinary income. In the first case, Emanuel $N$. Kolkey, ${ }^{100}$ the Tax Court agreed with the Commissioner. In the second case, Estate of Emest G. Howes, ${ }^{143}$ it disagreed. Both determinations were affirmed on appeal.

In both cases, since "feeders" were involved, the thinness of the operating company could be attacked directly, and hence the decisions are not directly in point in considering situations such as those described in Revenue Ruling 54-42.0 and the "business" plans under the New Mexico statute. Nonetheless, the decisions are obviously of great significance. Unfortunately, distinguishing the cases is not simple. Among the factors considered in Kolkcy, and the situation with regards the same item in Howes, are the following:

(1) The fairness of the price: In Kolkey, the price was about eight times after-tax earnings of the immediately preceding year, and about seven times book net worth, but the business was starting to falter badly. In Ho:ves, the price was about five times after-tax earnings of the immediately preceding year, but about thirty times after-tax earnings for any other year, and slightly less than net book value.

139 See text at note 62 supra.

11027 T.C. 37 (1956), af'd, 254 F.2d 51 (7th Cir. 1958).

11130 T.C. 909 (1958), nonacq., 1959 INT. REv. BuLL. No.32, at 7, nonacq. wilkdrawn \& acq- 3960 INt. REv. Bull. No. 6, at 8, af'd sub nom., Commissioner v. Johnsor, 267 F.2d 382 (1st Cir. 1959). See also W. H. Truschel, 29 T.C. 433 (1957), involving $t$ : same transaction. 
(2) The capital structure was unrealistic: In Kolkey, there was $\$ 1,000$ of stock, and $\$ 4,000,000$ of debt. In Howes, there was $\$ 1,000$ of stock, and $\$ 34,000,000$ of debt.

(3) There was no change in the operation of the business: The situation was essentially the same in this respect in both cases.

(4) Retained control over the business: In Kolkey, the sellers obtained 7-year management contracts, a pledge of the "feeder's" stock. and signed, undated, resignations of all its officers and directors. In Howes, the sellers received 20-year management contracts, and had one-hall of the total voting power over the business.

(5) Subscqucnt history: In Kolkey, the transaction went bad almost immediately, and the business was recaptured by the old owners, the business having sustained a substantial loss, and repayment being impossible. In Howes, profits dropped, apparently, to about 2 percent of the pre-sale level in three years, and some of the bonds were thereafter sold at 30 percent of face value.

(6) Down payment on the price: In Kolkey, the down payment was made after acquisition and dissolution of the business being acquired out of the cash received by the feeder in the dissolution. In Howes, the feeder borrowed the amount of the down payment on the security of the current assets to be received in the acquisition and dissolution.

Perhaps more revealing is the fact that in Howcs, involving a plan mechanically indistinguishable from the Kolkey plan, that latter case is mentioned only once, and then in these terms:

In that case we were confronted with an untried business, concededly speculative in nature, whose effectiveness had been immeasurably diminished by adverse rulings of Federal regulatory agencies, and which was purchased for a totally unrealistic purchase price. Furthermore, as a result of dire financial straits of the acquiring corporation, the transaction was rescinded, and the former orners reacquired their control. On those facts we held the purperted sale to be a sham which enabled the old stockholders to withdraw earnings and profits at favorable capital gains rates. The distinction is obvious. ${ }^{12}$

The essence of this obvious distinction is perhaps fairly stated to be a somewhat more charitable approach to the sellers in Howes. Consider the following:

From Kolkey:

The situation was practically the same as if Cowen and his associates had purpcrted to "sell" their business for $\$ 4,000,000$ to a penniless individual.:43

i12 Estate of Ernest $\mathrm{F}$. Howes, 30 T.C. 909, 925-26 (1958).

142 Emanuel N. Kolkey, 27 T.C. 37, 59-60 (1956). 


\section{From Howes:}

Since the sellers were dealing with a purchaser who was in no position :o effect an outright payment of the purchase price, ${ }^{[139]}$ it was decided to utilize the profits of the business to make the agreed-upon payments, and a bond issue was devised to accomplish this end. ${ }^{214}$

All of this can do more than underscore the fact that in any of the revenue bond cases the best assurance of success will be respectability.

While it is impossible to synthesize any general "rule" assuring Howestype treatment, several factors appear worthy of mention. First, it is clear that the price set should be "fair and reasonable" rather than "grossly unrealistic." Second, providing the acquiring corporation with some indapendent substance is desirable; especially so if the down payment on the price can be made out of the corporation's own funds. Third, the presence of members of the selling group in control positions in the acquiring corporation is undesirable. The Commissioner's recent acyuiescence in Howes clearly indicates that it is possible to use the basic plan, provided the arrangements made are reasonable and fair. One major strength of the New Mexico plans would lie in the very strong evidence of "business purpose" afforded by the relocation essential to the New Mexico act, and the fact that upon the outcome of the case may depend the economic well-being of an entire community.

Of course, concessions to business desires are going to have to be made. The completely tax-risk-free transaction would undoubtedly contain elements unpalatable to the seller. Hence there must be a balancing of the increased risks involved with each additional factor suggesting failure to divorce buyer and seller.

The most powerful check on permitting business desires to overwbelm necessary caution is the rather high price charged for erring in favor of business desire. All of the payments received by the seller are converted from return of capital, capital-gains and tax-exempt interest, deductible in whole or in part by the buyer, into nondeductible dividend income, subject to tax at ordinary income rates to the extent of the earnings and profits of the business. "15 And, since the entire payments are made out of earnings, it would seem that everything received would be subject to the same disastrous treatment.

\section{Method of Rcporting Gain on the Salc of a Business}

Recause realization of the full price agreed to be paid for the business is subject to the rather substantial contingency that the business continue to earn profits sufficient to service the bonds, the problem of when and how the "paper profit" on the sale of a business should be reported is of some

1432 Compare with this, the "penniless" characterization in Emanuel N. Kolkey, supre note 143 .

14t Estate of Ernest G. Howrs, 30 T.C. 909, 923 (1958).

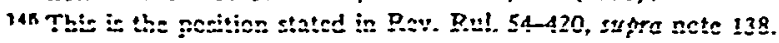


significance. It would appear that either of two favorable methods might be available.

In view of the apparent unsaleability of the bonds during the early years following the sale, ${ }^{116}$ it might be possible to use the "cost recovery" method, under which the earliest payments of principal are deemed applicable entire to basis, and no profit is reported until the entire basis has been recovered. ${ }^{17}$ 'This technique might be sufficiently desirable to warrant the sellers' submitting to restrictions upon the sale of the bonds for a period of years, so as to further demonstrate the lack of any fair market value of the securities. ${ }^{\text {ts }}$ Such restrictions, imposed in words, would not seem substantially more severe than those imposed by the market.

Otherwise, the installment method ${ }^{140}$ of reporting the gain would appear to be available, assuming the purchase were made by the municipality whose bonds were used as evidence of the indebtedness. In this connection, it might be noted that most of the negotiating, except in transactions involving only one business, is likely to be done with promoters representing the acquiring corporation, rather than the city. Seilers would be well advised to exercise some caution in the extent to which the transaction is firmed before the city officials are called in. ${ }^{180}$

Assuming that the purchase is in fact made by the municipality, there appears no reason for doubting that municipal bonds would constitute "evidence of indebtedness" witbin the meaning of section 453 of the Internal Revenue Code of $1954 . .^{132}$ Of sourse, the bonds should have serial maturities, in order that portions of the payments be received in different years. ${ }^{132}$

\section{CONCIUSIONS}

Typically, the tax attorney will be called upon immediately after the client's return from a lengthy visit with sireus expounding the merits of the New Mexico Commercial and Industrial Project Revenue Bond Law. By this time, the businessman will have convinced himself that the salubrious New Mexico climate, picturesque towns, and other non-tax adyantages make it imperative that the business be relocated in that State. Under these

116 See text following note 118 supra.

147 See Treas. Reg. 1.453-6(a)(2) (1958). The courls have been more generous. See Stinson. Installment Sale of a Business, N.Y.U. ISTu INST. ON FED. TAX 643 (1957).

138 This is generally understood to eliminate any fair market value and to render proper the use of the "cost recovery" lechnique. See Nina J. Ennis, 17 T.C. 465 (1951).

110 Ist. RIv. Cooz or 1954, 453.

130 Where the unpaid portion of the price is evidenced by obligations of one other than the purcbaser, the entire gain is reportable at once, these obligations constituting simply "property" received in the exchange. See Caldwell v. United States, 114 F.2d 095 (3d Cir. 1940); G.C.M. 11846, XII-1 Cos4. BCII 113 (1933).

181 See definition of "bond" in Irt. Rxv. Conx or 1954, 8 i71(d), as a tspe of "evidence of indebledness."

132 See Rev. Rul. 56-587, 1956-2 Cux. Bulx. 303. 
circumstances it is frequently difficult to assay the glittering promises and hoped-for results.

If any general conclusion is possible, it seems that it would be this: If the relocation does in fact make economic sense, without the use of the statute, then the statute can be effectively used for gold-plating the relocation. If, however, the only justification for a proposed relocation is the nromise of the statute, that promise is quite likely to prove no more than iron pyrite.

It is basically a problem of "business purpose." 153 Where once relocation has been determined upon as a sensible course, then it is possible to approach the statute calmly, and determine which of its many possible applications best fits the problems of the particular case. Perhaps a simple "building" plan, with a leasing from the city without a recapture clause will suffice to offset any expense of relocation. Or perbaps the creation of a subsidiary to make acquisitions of several unrelated companies, the former owners of which being given no control over the subsidiary, will provide a sound vehicle for desired expansion. Inventiveness can be given free rein, tempered by the knowledge that any gain is pure profit, and that the possible greater should be yielded in favor of the certain lesser.

On the other hand, where it is a particular application of the statute that is the only justification for a relocation, the facts must be forced into the mold of that transaction. It may well be that this can be accomplished in a given case. But one is not likely to be able to give any real assurances until several years after the fact-a most unfortunate time to discover there has been an error in view of the consequences.

Fortunately, the governing bodies of the responsible municipalities in New Mexico recognize that nothing is to be gained through luring businesses to the State, only to have them crushed under an unexpected tax burden, or to fail as a result of basic unsoundness. Even though the bonds issued are revenue bonds, there is generally a certain pride in the municipal name which precludes its use in connection with blatantly impossible schemes.

These responsible municipalities view the statute not as an inducement, but rather as a stimulus to further investigation of their other attributes. Viewcd in this fashion, there seems to be, in addition, a good chance for tax benefits unavailable anywhere else.

153 Throughout this paper, little mention has been made of the entire problem of "business purpose" in the thought that it would loom sufficiently large to negative any necessity for belaboring it. Brief mention might be made, however, of the possihility of the problems suggested by cases such as Commissioner v. Court Holding Co., 324 U.S. 331 (1945), in view of the fact that most of the negotiations for any sale will be carried on with the promoters of the acquiring corporation, rather than with the officials of the municipality ostensibly making the acquisition. And, of course, the old standby, Gregory v. Helvering, 293 U.S. 465 (1935). These are problems which must aiways be recognized. 
On the other hand, some of the plans presently being considered by various municipalities are, at least apparently, rather speculative. It is unfortunate but true that the members of governing bodies of municipalities desperate for development can believe too blindly in the future, and be bullied too readily into the belief that no harm can come of the issuance of revenue bonds. ${ }^{25} \mathrm{It}$ is to be hoped that the potential benefits of the statute are not dissipated in pursuit of impossible schemes which will adversely affect bona fide attempts to utilize the statute to the mutual advantage of the State of New Mexico and relocating businesses. 


\section{California Law Review}

MEMEER NATIONAL AND WESTERN CONFEREACES OF IAW REVIEWS

Published Five Times Yearly by Students of the School of Law of the University of California, Berkeley, California. Indexed in Index to Legal Periodicals and Public Afiairs Information Service.

\section{BOARD OF EDITORS}

\begin{tabular}{|c|c|c|}
\hline \multicolumn{3}{|c|}{$\begin{array}{c}\text { Gare A. ScHLESSINGer } \\
\text { Editor-in-Chief }\end{array}$} \\
\hline $\begin{array}{l}\text { JAsces W. Drwwortz } \\
\text { Note \& Comment Editor }\end{array}$ & $\begin{array}{c}\text { RICEARD ALEXaNider BURT } \\
\text { Managing Editor }\end{array}$ & $\begin{array}{l}\text { Berenard E. Jacos } \\
\text { Article Editor }\end{array}$ \\
\hline \multicolumn{3}{|c|}{ Assistant Editors } \\
\hline $\begin{array}{l}\text { ALBERT J. FinK } \\
\text { FrEDERIC L. KirGIS, JR. } \\
\text { Notes \& Comments }\end{array}$ & $\begin{array}{c}\text { JomN D. HusseY } \\
\text { Maraging }\end{array}$ & $\begin{array}{c}\text { FREDERICT K. KUNZEI } \\
\text { Articles }\end{array}$ \\
\hline
\end{tabular}

Revising Editors

BRUCE A. BERRY

ROBERT M. Brown

Donatd B. Day

ROBERT L. Garst

Thousas H. GeE

Deraid E. Granberg

Cecr HuNT
LEO KANOWITZ

RICEARD H. LEVIN

Davm B. LFNCH

MatThew P. MrtcenLL

Donato J. Morgan

RICEARD B. MORRIS

Marcot F. Piant

MASON WIILRICE

General Secretary

MarjorIE DevereuX

\section{Contributors to This Issue}

JAsres W. DIIWORTE

NEISON ENAXARK

JOANAE M. GARVEX

VICTOR A. HEBERT

Frederic L. KIRGIS, JR.
RICEARD LasoM

Frank H. Lang, Jr.

MrRzo A. Mmicevice

Doxato D. Roberts

Gary A. Schressinger 